\title{
Research on Status Quo of Music Teaching and Talents Training Mechanism in Normal Colleges and Universities in China
}

\author{
Huihua Liu \\ Feixian Campus \\ Linyi University \\ Feixian, China
}

\begin{abstract}
Going with the social development, education has been in face of all kinds of challenges and opportunities and the roles of music that has been playing in the normal education system are becoming more and more important. This article makes analysis of the developing music teaching in normal colleges and universities in order to provide references to those concerned to fully master the overall situation of music teaching in the country. Based on the point, the author conducts deep studies upon the concept and education mode of training students in music teaching and explores a talent training mechanism which conforms to the general requirements of educational reforms in the current period.
\end{abstract}

Keywords-music teaching in normal colleges and universities; status quo in teaching; talent training mechanism

\section{INTRODUCTION}

The Master Plan for Art Education in Nationwide Colleges and Universities points out clearly: "Art education is the major point and way for carrying out the aesthetic education in colleges and universities and also an approach powerful to strengthen the construction of socialist spiritual civilization, improve students' moral standards imperceptibly, cultivate noble sentiments and promote the development of intellectual and physical and mental health. As an important part of college education, the music teaching plays a special role that can not be replaced by subject teaching". In face of current trends of educational reform and development, how to train music talents under new requirements by the society has been a key point attracting most eyeballs of normal colleges and universities. Yet the time is changing, so is the education, only the talents meeting the social trend can adapt themselves and contribute to the society, accordingly it has been a must to further the research on the training modes of music talents in normal colleges and universities.

\section{Problems EXISTING IN THE CURRENT MusiC TEACHING AND TALENT TRAINING MECHANISM IN COLLEGES AND UNIVERSITIES}

\section{A. Lagging Education System}

The 21st century is a new stage where the market economy system has been predominant, which produces a great influence to the education. However, there are still a lot of normal colleges and universities where the traditional educational system in the planning economy time is followed for the talent training in the music teaching. Thus it can be seen that the traditional educational system is unable to well go with the market economy system which is widely carried out under the time of socialist construction, therefore, the lagging system in music education has become an obstacle for its development.

\section{B. Inconsistency of Talent Training with Social Demand}

The 21 st century is an era of knowledge economy and even more the information technology. In order to advance the development, the society has more new requirements on talents, compared to the monotonous talents, the interdisciplinary talents are better to meet the social demands. Yet colleges and universities have failed to keep up with the pace of the knowledge economy, which are still focused on the monotonous talents, especially in music education, such talent training is unable to satisfy the social demand of the time.

\section{Outdated Teaching Modes and Teaching Equipment}

Nowadays, the Internet of Things has become an important part in the daily life of the people and the information technology plays an increasingly important role in all fields. Multimedia education has become an important way to improve the teaching quality and efficiency. However, the music teaching in normal colleges and universities fail to keep up with the social development, still using traditional educational tools as well as outdated teaching equipment, which do bad to reflect students' roles in class teaching besides, it makes all class teaching boring. Besides, it is unable to train students' innovative thinking or stimulate students' enthusiasm to study. 


\section{Examination-orientated Education Mode}

Nowadays, quality education is advocated both at home and abroad, conforming to the trend of the time. Yet, current music teaching in colleges and universities is still following the examination-oriented education mode, which brings no good to the development of music education in normal colleges and universities.

\section{E. Inconformity of Educational Mode with Training Objective}

The music education in normal colleges and universities is just copied directly from the quality education mode in music colleges and schools, yet due to the particularity of the music education in colleges and universities and its difference from the music colleges, it is different from the talent training objectives of their own. Actually the direct copy of teaching patters by normal colleges and universities from music colleges causes the inconsistency to the training objective of their own, as a result, the music teaching in colleges and universities are severely restricted.

\section{F. Outdated Concepts in Teaching}

The concept of music teaching in normal colleges and universities fails to keep up with the pace of development of the time, which still remains in the thinking mode of the planned economy. The buttoned-down teaching concept also causes the separation of teaching contents, methods, course structure and so on from the development of the times. Besides, during the music teaching, teachers take over stress on the importance of professional knowledge, ignoring the training of students' capabilities in innovative spirit and creative thinking, which is bad to the improvement of students' overall quality.

\section{IMPROVE STATUS QUO OF MUSIC EDUCATION IN COLlEgES AND UNIVERSITIES AND PERFECT THE TALENT TRAINING MODE}

\section{A. Clearly Determine the Talent Training Objective}

The music education in normal colleges and universities should set up a concept of talent training in line with the development of the times, breaking through the outdated educational concepts and clarifying the orientation of teaching. For example, based on the original advantages, we should introduce school-running means advanced in the times. Considering the characteristics of music talents who will teach music at primary and middle schools after graduation and an orientation for the talent training, we should be devoted to training versatile and interdisciplinary talents, changing the original "versatile" into "expert in one but good at more". The students majoring in music in normal colleges and universities shall not only own professional skills in music but also grasp knowledge relative to pedagogy and literary arrangement. Meanwhile, the students majoring in music shall know methods of music teaching and juvenile psychology in cognition to some degree, thus, the talents gradating from normal colleges and universities can meet the social demand, competent for the music education in primary and middle schools.

\section{B. Develop New Concepts for Teaching and Change Teaching Modes}

For a long time, the music education in normal colleges and universities has been copying the school-running modes and teaching methods of professional music colleges, which emphasizes the professional skills of students but ignore those relative to the education. It has also caused the deviation in the teaching contents of music education in normal colleges and universities, having a separation from the posts that the students will take for music education in primary and middle schools. Therefore, the music education in normal colleges and universities shall set up new concepts, adopt advanced teaching methods and make sure of the reform direction. For example, first of all, we must distinguish the school-running concepts between professional music colleges and teacher training music colleges, make sure of the school-running objective of the teacher- training music colleges, completely understanding the objective of talent training in teachertraining music colleges is to train music teachers, especially cultivating faculties for primary and middle schools. Thus, we can set courses and class hours according to the characteristics of ourselves and establish a talent training mechanism meeting the situations of teacher-training music colleges.

\section{Enrich the Teaching Contents and Optimize the Course Structures}

Students studying music in teacher-training (normal) colleges and universities shall strengthen the courses relative to practical skills, for example, singing technique of vocal music and keyboard playing skills are two very practical courses, which need a long term continuous accumulation. However, currently only two years are set for the two courses as essential course, for the students studying music in teachertraining colleges, obviously it is very difficult for them to grasp and apply it skillfully within two years, but they are required courses for them, accordingly the two courses can be set as required courses together with the study term prolonged for a year.

In addition, compared with the traditional music education model and teaching methods, the music teaching via multimedia music teaching system make the music teaching contents more colorful, reducing teachers' burdens in work and making the teaching process more interesting. Currently audio production and computers have been widely adopted in the music creation and dance. Therefore, the teacher-training colleges should be in line with the society, setting new computer-aided music courses, and connect the computer-aid music production with courses as vocal music and basic music theories and the like to further make the course contents intuitive and vivid, which stimulate students' interests in music $\mathrm{s}$ and improve the teaching efficiency.

The lectures about edge-cutting subjects shall be also supplemented to further perfect the talent training model. For example, edge-cutting lectures such as acoustics, recording production, poetry and odes and songs can be added. This will be working as a great support for the students serving as music teachers and providing extracurricular tutoring in the future. Besides, the students may get a full understanding of the 
history of Chinese music and train the cultural quality of their own through the poetry and songs leaning.

\section{Intensify the Teaching Practice and Promote the Practicality of the Talent Training Model}

The teacher-training music college and universities are mainly to train music teachers for primary and middle schools, it is known that the post of music teacher is highly practical, which have higher requirements in the practical application of music skills and theoretical knowledge. Therefore, it needs to intensify the practicality in teaching, promote the talent training model to be more perfect, making the talents trained in full line with the social demand. For example, we can access to social cultural classrooms, and hold some parities associated with social fields, from which the students may form a relatively clear understanding of the actual situation. In addition, we can also hold some activities relative to primary and middle schools and social cultural tutoring through the students may personally touch the social trends. Based on the understanding of social demand and a timely adjustment of what you are learning, the students will for a more clear understanding of the career planning of their own.

\section{E. Innovate Teaching Methods and Improve the Talent Training Mode}

The teaching shall have a special subject when in professional music colleges or teacher-training colleges and universities, so teaching mode can innovated to promote the talent training model to more conform to the new situation of social development. For example, we can connect individual class, group class and collective class. Furthermore, vocal music is taught via small class in most colleges, actually the class containing general theoretical knowledge and practice class can be integrated to a big class for teaching to form a close connection between them.

\section{CONCLUSION}

With the accelerated pace of the knowledge economy, the society will have requirements varying with the time. Due to the increased emphasis on the abilities of comprehensive quality, the music teaching, belonging to the aesthetic education in the high education, is also becoming more and more important, so the teacher-training-based music education should keep up with the pace of social development, break traditional concepts in education, set up new concepts of talent training and create a teaching system in line with the social development so as to build a high quality music teaching team.

\section{REFERENCES}

[1] Li Wei, Research on Status Quo and Improving Strategies of Professional Quality of Vocal Music Teaching in Normal Colleges and Universities [D] Northeast Normal University. 2015

[2] Luo Xiao, Research on Comprehensive Abilities of Students Majoring in Music Education in Teacher Training Colleges under New Curriculum Standards [D] Yunnan Normal University, 2013

[3] Su Jun, Discussion on Music Teaching in Primary and Middle Schools From Status Quo of Music Education in Teacher Training Colleges and Universities [J] Art Education, 2010, 08:50+69
[4] Yang Chunlin, Status Quo and Countermeasures of Folk Music Teaching in Normal Colleges and Universities [J] Journal of Nanchang College of Education, 2012, 06:87+89.

[5] Yuan Zihan, Status Quo and Problems Existing in Pop Music Teaching of Music Education in Normal Colleges and Universities [J] Music Space, 2014,19:83. 